\title{
Assessing the impact made by groundwater processes and undermining on coal pit wall stability
}

\author{
Mikhail M. Karablin ${ }^{1 *}$, Sergei M. Prostov², Nikolai A. Smirnov ${ }^{3}$ \\ ${ }^{1}$ Kuzbassgiproshakht, Kemerovo, Russia \\ 2 T. F. Gorbachev Kuzbass State Technical University, Kemerovo, Russia \\ ${ }^{3}$ Innovation Company Kuzbass-NIIOGR, Kemerovo, Russia \\ *e-mail: karablin.mm@gmail.com
}

\begin{abstract}
Introduction. The reliability of geomechanical prediction depends on the level of detail of databases covering geological structure, geometry and physical properties of the rock mass under investigation. In order to improve the accuracy of coal pit wall stability prediction, following the generalization of databases containing geological survey, groundwater monitoring, geophysical sounding and mine surveying, it is advisable to construct three-dimensional geological-geophysical models accounting for the main adverse factors, and thereafter search for the most hazardous section.

Research aim is to predict wall stability according to the developed algorithm based on the threedimensional geological-geophysical model.

Research methodology includes a search for the most hazardous rock mass site section by the ratio between shear and retaining forces within the established zones with anomalous physical characteristics. Results. By generalizing databases containing geological studies, groundwater monitoring, geophysical sounding by the method of electrical resistivity tomography, and mine surveying, a three-dimensional geological-geophysical model has been constructed of a wall loaded with "heap of dry rock atop of the hydraulic dump" man-made structure and undermined by underground works. The trial site stability has been predicted for the true state of mining. Comparative analysis of the obtained data has been carried out. Summary. The combination of natural and man-made factors, including hydrogeological conditions of the territory, seasonal and climatic behavior, tectonic faulting of the deposit and shear zones connected with undermining result in the development of a rather complex geological structure of the wall which includes local deconsolidated and waterlogged zones significantly reducing the stability of the pit slope. At the trial site of Kedrovsky pit due to spatial and temporal alternation of properties and state of rock within the landslide hazardous zone, the variation range of the factor of safety in six typical sections amounts $n=1.06-2.39$. For that reason the objective prediction of slope stability in similar conditions (in addition to geological survey and hydrogeological observations data analysis) should include geophysical monitoring of anomalous zones origination and development, hereupon creation of a treedimensional geological-physical model, and the automated calculation of the factor of safety including repeated selection of the most hazardous section.
\end{abstract}

Key words: man-made rock mass; groundwater; slope stability; electrical resistivity tomography; three-dimensional geological-geophysical model; factor of safety.

Introduction. The accuracy of pit slope stability prediction depends on the reliability of a geological-geophysical model which should take account of the cumulative effect of adverse factors, namely physical-geographical, engineering-geological, mining, and hydrogeological. Negative impact made by a group of physical-geographical and mining factors is predicted with a high degree of accuracy as early as at the stages of surveying and design. The reliability of assessing engineering-geological factors impact on the wall stability is conditioned by the size of a database containing physicalmechanical parameters of lithotypes, natural planes of weakness and various zones in the wall; the database grows with field development. The impact of hydrogeological factors on wall's stress state is due to, firstly, rock strength decline in water-saturated zones, secondly, hydrostatic pressure forces as a result of combined action of hydrostatic 
weighing and hydrodynamic forces on the sliding wedge. Data on the condition of groundwater occurrence obtained at the stage of surveying characterize only static levels which change constantly in the course of mining. Researches [1-4] have shown that the majority of wall instability instances occur in complex hydrogeological conditions. For that reason, the problem stabilizing mine slopes when developing such deposits cannot be solved to the full extent without hydrogeological observation. Creation of classical hydroregime observation networks makes it possible to mark out aquifers within the limits of section lines; water wells interpolation of data is inevitable between the sections. In order to improve the reliability of the data it is advisable to apply geophysical methods based on electromagnetic fields application. Research done in this field have shown their effectiveness as soon as zones with anomalous humidity are sufficiently contrasting by electrical resistivity [5-11].

Table 1. Physico-mechanical properties of lithotypes and natural planes of weakness

Таблица 1. Физико-механические свойства литотипов и естественных поверхностей ослабления

\begin{tabular}{l|r|r|c}
\hline \multicolumn{1}{c|}{ Lithotype (contact of beds) } & $\rho, \mathrm{kN} / \mathrm{m}^{3}$ & $C, \mathrm{kPa}$ & $\varphi$, degrees \\
\hline Quaternary deposits & 20.1 & 54.0 & 16 \\
Weathered original rock & 22.8 & 153.0 & 33 \\
Unweathered original rock & 24.6 & 274.7 & 33 \\
Fault zone & 20.9 & 47.1 & 15 \\
Coal & 13.2 & 107.9 & 28 \\
Aggradation rock & 19.1 & 24.5 & 12 \\
Dry spoil & 18.1 & 14.7 & 32 \\
Caving zone & 19.6 & 0.0 & 31 \\
Fractured zone & 20.6 & 15.3 & 32 \\
Contacts: & & & \\
$\quad$ Sandstone and siltstone & - & 35.3 & 20 \\
$\quad$ Quaternary and original rock & - & 20.6 & 14 \\
$\quad$ Coal and host rock & - & 25.5 & 14
\end{tabular}

$\rho$ - volumetric weight; $C$ - cohesion; $\varphi$ - angle of shear resistance.

The authors have generalized the results of studies on the groups of adverse factors in the conditions of Kedrovsky coal mine. Research aim is to predict wall stability according to the developed algorithm [12] based on the three-dimensional geologicalgeophysical model.

Research methodology. In order to construct three-dimensional geologicalgeophysical model of the wall, field survey data, geophysical research and hydrogeological observations were used.

The estimates of physical-mechanical properties of lithotypes and natural weakness planes have been obtained as a result of generalizing VNIMI research from previous years.

In order to assess water content in the wall, actual water levels have been measured in four water monitoring wells and geophysical research by the method of electrical resistivity tomography with SKALA-64 electrical exploration equipment by three profile lines $1345 \mathrm{~m}$ long (profile 1 is $555 \mathrm{~m}$, profile 2 is $475 \mathrm{~m}$, and profile 3 is $315 \mathrm{~m}$ ). Results have been processed using specialized software to interpret electrical resistivity tomography data.

In order to determine the borders of zones with structurally weakened due to stope roof collapse, shear zone has been constructed. 
Wall stability has been predicted for the actual state of mining and dumping by the method of composition of forces.

Results. The algorithm of predicting wall stability using geological-geophysical models is based on the generalization of databases covering physical-mechanical parameters of the wall, geometry of mine workings and zones with anomalous humidity. The procedure of searching for the most hazardous section contains repeated calculations of the factor of safety $n$ for a set of vertical sections, built with the predefined linear and angular pitch [12].

Table 2. Results of measurements of actual water levels in observation wells Таблица 2. Результаты замеров фактических уровней воды в гидронаблюдательных скважинах

\begin{tabular}{|c|c|c|c|c|}
\hline$Z, \mathrm{~m}$ & $H_{\text {well }}, \mathrm{m}$ & $H_{\text {water }}, \mathrm{m}$ & $Z_{\text {water }}, \mathrm{m}$ & Test date \\
\hline \multicolumn{5}{|c|}{ Well 2603} \\
\hline \multirow[t]{3}{*}{186.0} & 80 & 56.5 & 129.5 & March 2017 \\
\hline & & 74.2 & 111.8 & April-May 2017 \\
\hline & & No water & No water & June 2017 \\
\hline \multicolumn{5}{|c|}{ Well 2604} \\
\hline \multirow[t]{3}{*}{165.0} & 65 & 10.7 & 154.3 & April 2017 \\
\hline & & 30.0 & 135.0 & May 2016 \\
\hline & & No water & No water & June 2017 \\
\hline \multicolumn{5}{|c|}{ Well 2605} \\
\hline \multirow[t]{3}{*}{195.0} & 74 & 53.4 & 141.6 & April 2017 \\
\hline & & 68.7 & 126.3 & May 2016 \\
\hline & & No water & No water & June 2017 \\
\hline \multicolumn{5}{|c|}{ Well 2606} \\
\hline 121.1 & 67 & 19.5 & 101.6 & April 2017 \\
\hline
\end{tabular}

$Z$ - wellhead elevation; $H_{\text {well }}$ - well depth; $H_{\text {water }}$ - depth of water table; $Z_{\text {water }}-$ water table elevation.

The wall of the Kedrovsky mine under investigation represents a part of the edge within the borders of the profile lines 400-510 with heights from +120 to $+195 \mathrm{~m}$ (abs.). The indicated geological sections analysis determined that in the site under investigation in the upper part of the geological section mainly sandstone occurs underlain by siltstone which is enclosing rock for Vladimirovsky coal bed.

Vladimirovsky roof level within the limits of geophysical profiles 1 and 2 change from +138 to $+140 \mathrm{~m}$ (abs.). Within the limits of geophysical profile 3, Vladimirovsky roof level is $+67 \mathrm{~m}$ (abs.). The thickness of Vladimirovsky bed within the limits of geophysical profiles is $3-4 \mathrm{~m}$. Viktorovsky bed has also been discovered in the site under consideration occurring within the limits of geophysical profiles 1 and 2 near the surface. This bed is characterized by lesser thickness $(0.4-0.6 \mathrm{~m})$ and frequent wedging out.

The site under investigation reveals ruptures I and II discovered both within prospect lines XVIII (profile 410) and XX (profile 530).

Physical and mechanical properties of lithotypes and natural weakness planes according to VNIMI research from previous years are shown in table 1.

According to the results of groundwater survey prior to mining, groundwater in this territory have been developing at valley side slopes and tributaries of the Bolshaya Promyshlennaya, Chesnokovka and Kedrovka rivers transiting from watersheds to thalwegs where the main discharge occurred. Piezomeric surface roughly reproduced 
the lay of the land. Actual hydrogeological conditions of the site are extremely complex at the present time. It is primarily conditioned by the fact that within the limits of the mine take the indicated rivers either ceased to exist or their run-off was regulated. Besides, quaternary deposits are stripped by hydromonitors, water aimed for these works is cumulated in reservoirs along the river valleys, while the pulp is discharged into the hydraulic waste disposals. A cone of depression has developed over the years of pit operation, the dimensions of which don't exceed the distance to reservoirs and hydraulic waste disposals deliberately, creating the "circulation" of groundwater and surface water in this territory.

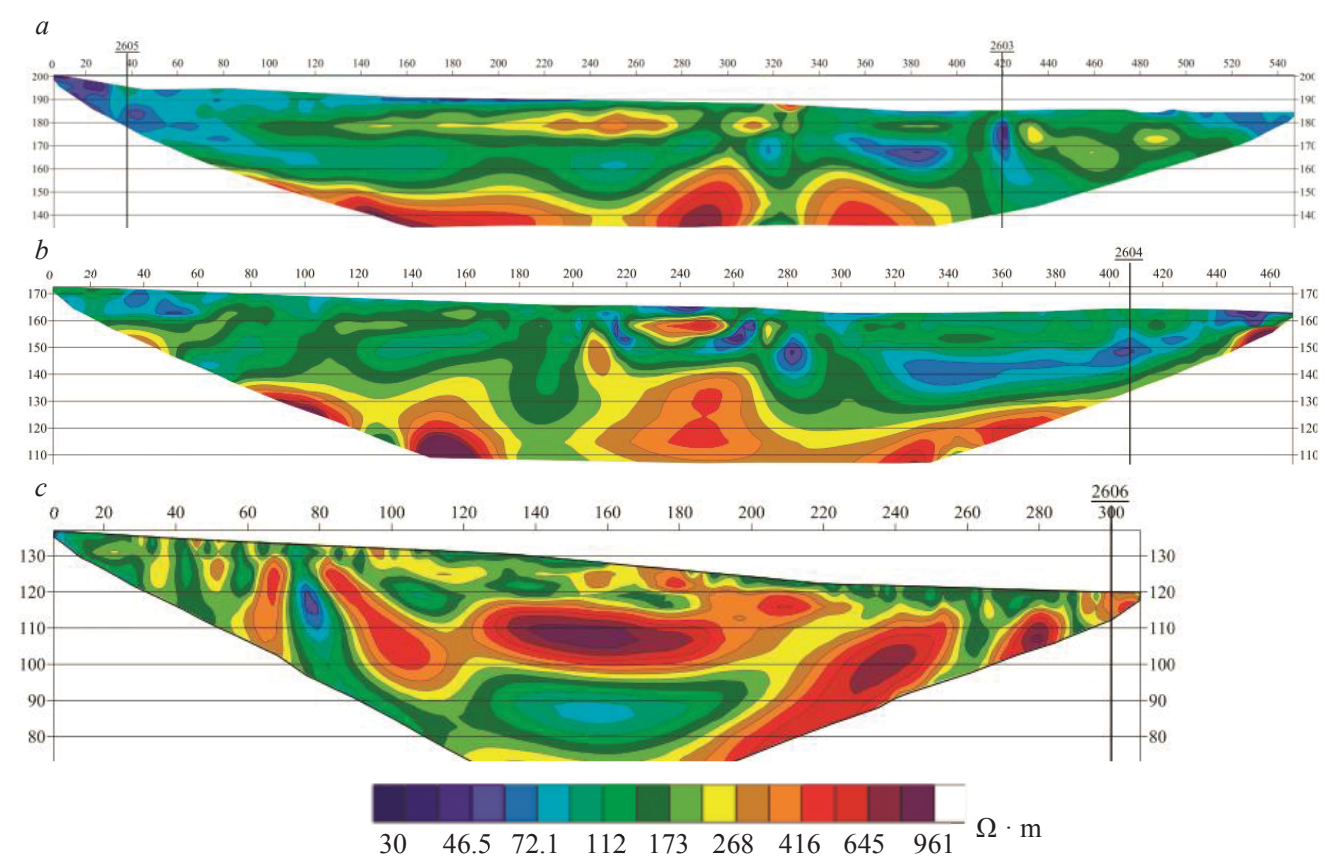

Fig. 1. Geoelectric sections along profiles $1-a, 2-b$ and $3-c$

Рис. 1. Геоэлектрические разрезы по профилям $1-a, 2-b$ и $3-c$

It should be noted that not far from the considered site, Vladimirsky shaft mined for coal having undermined the man-made structure "heap of dry rock atop of the hydraulic dump" in the wall. The scheme shows that mine takes of the enterprises share the borderline. In section, the depth of the shaft does not exceed $100 \mathrm{~m}$, for that reason the underground mines "catch" the upper part of the groundwater flow.

The following aquifers are well-presented at the territory of Kedrovsky pit:

- impervious central upper quaternary horizon (a QII-III): observations over the tributaries flowing into the pit's mine workings have shown that there are very little tributaries from loam soil;

- aquifer Lower Permian complex of the Kemerovo formation (P1 km). Lower Permian sediments within the limits of the deposits are ubiquitous. Water-bearing materials of the complex are interbedded by fractured sandstone, siltstone, argillite and coal veins. Fine-grained sandstone builds up to $60 \%$ of the quarry.

Groundwater survey in the field have shown that inundation degree of original rock is chaotic and uneven both in the scheme and in the open pit and depends on sediments displacement, lithological composition and fracture intensity, as well as on their geomorphic features. Groundwater refer to spring and autumn recharge type with a marked predominance of the former. Increase of rivers is observed during intensive 


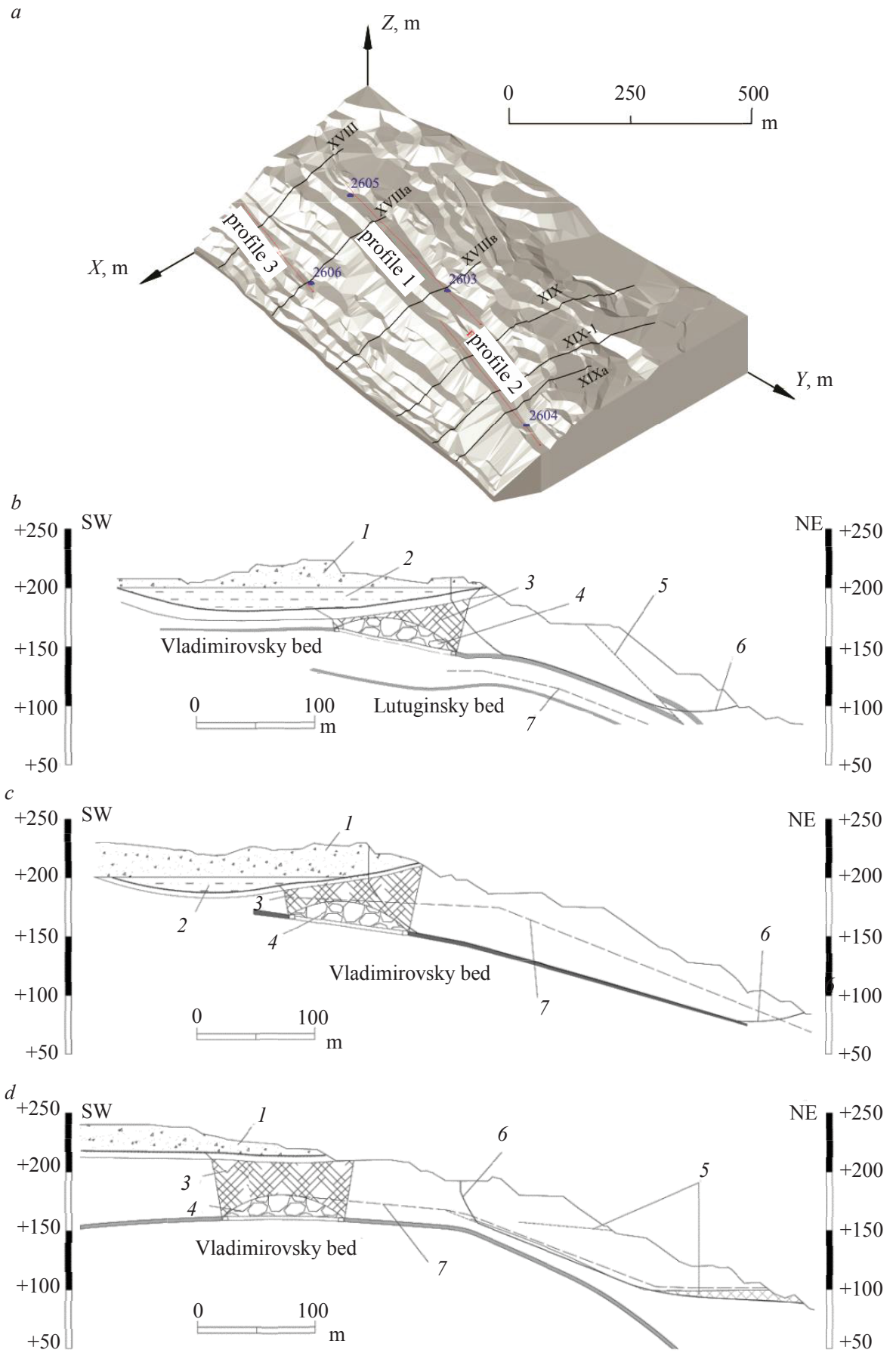

Fig. 2. Three-dimensional geologic and geophysical model of the open-pit wall $-a$ and geologic sections XIX $-b$, XVIIIb $-c$, XVIIIa $-d$ :

1 - dry overburden; 2 - aggradation deposits; 3 - fractured zone; 4 - caving zone; 5 - fault; 6 - failure surface; 7 - water table as of April 2017

Рис. 2. Объемная геолого-геофизическая модель прибортового массива - $a$ и геологические разрезы XIX $-b$, XVIIIв - $c$, XVIIIa $-d$ :

1 - породы отвала «сухой вскрыши»; 2 - намывные отложения; 3 - зона трещин; 4 - зона обрушений; 5 - разрывное нарушение; 6 - наиболее напряженная поверхность скольжения; 7 - уровень подземных вод на 04.2017 г. 
melting of snow from April till June. The shape of the piezometric surface of groundwater in virgin conditions roughly reproduced hypsographic relief, but at the present time a cone of depression has developed here over the years of pit operation. The results of actual water levels measurement in water monitoring wells are shown in table 2 .

Let us consider geoelectric sections obtained after geophysical measurements interpretation. The measurements have been carried out by the method of electrical resistivity tomography of three profiles (fig. 1). It should be noted that there was no water in wells at the time of geophysical measurements.

Profile 1 was located in horizons $+185 \ldots+195 \mathrm{~m}$ (abs.), the length of the profile was $555 \mathrm{~m}$. In the initial part of the profile, at the distance of $0-30 \mathrm{~m}$ from the initial part, and in the upper part of the pit down to the depth of 1-5 m, a layer of piled rock with electrical resistivity less than $50 \Omega \cdot \mathrm{m}$ has been marked out. Almost along the whole profile in the upper part of the pit down to the depth of 10-20 m, the layer of sandstone is distinguished with electrical resistivity of mainly $120-250 \Omega \cdot \mathrm{m}$. Sites with reduced electrical resistivity in the upper part of this layer may be conditioned by intensive weathering of sandstone. At the distance of $420 \mathrm{~m}$ from the start of the profile in the upper part of the pit, the anomaly of reduced electrical resistivity is observed associated with well shaft 2603. Along the whole profile within the range of depths of 15-40 m, a layer with electrical resistivity $50-80 \Omega \cdot \mathrm{m}$ is distinguished, apparently associated with the zone of clastic rock of rupture. Within this layer, at the distance of 350-400 m from the start of the profile, an area with electrical resistivity less than $50 \Omega \cdot \mathrm{m}$ has been discovered, which may correspond to the site of high humidity in the rock mass. In the lower part of the pit at depth ranging from 35 to $55 \mathrm{~m}$, a layer of siltstone with Vladimirovsky coal bed is singled out. For this bed electrical resistivity makes up mainly $270-500 \Omega \cdot \mathrm{m}$.

Profile 2 was located in horizons $+163 \ldots+173 \mathrm{~m}$ (abs.), profile length made up $475 \mathrm{~m}$. Almost along the whole length of the profile in the upper part of the quarry down to the depth of 5-20 m a layer of sandstone is distinguished with electrical resistivity of mainly $120-200 \Omega \cdot \mathrm{m}$. Sites with reduced electrical resistivity in the upper part of the layer are conditioned by intensive weathering of sandstone. Site with high electrical resistivity at the distance of 230-250 m from the start of the profile may be connected with Viktorovsky bed which becomes thicker here. Along the whole length of the profile at depth ranging mainly from 10 to $25 \mathrm{~m}$, a layer with electrical resistivity of $50-80 \Omega \cdot \mathrm{m}$ is distinguished, apparently associated with the zone of clastic rock of rupture. Within this layer, at the distance of 260-285 $\mathrm{m}$ from the start of the profile, an area with electrical resistivity less than $50 \Omega \cdot \mathrm{m}$ has been discovered, which may correspond to the site of high humidity in the rock mass. In the lower part of the pit at depth ranging from 15 to $55 \mathrm{~m}$, a layer of siltstone with Vladimirovsky coal bed is singled out. For this bed electrical resistivity makes up mainly $270-500 \Omega \cdot \mathrm{m}$. It should be noted that towards the end of the profile the zone of clastic rock surfaces the bench.

Profile 3 was located in horizons $+120 \ldots+138 \mathrm{~m}$ (abs.), profile length made up $315 \mathrm{~m}$. In the upper part of the quarry down to the depth of 10-15 $\mathrm{m}$, a layer of sandstone is distinguished with electrical resistivity of mainly $120-250 \Omega \cdot \mathrm{m}$. At depth ranging mainly from 10 to $40 \mathrm{~m}$, zones with electrical resistivity higher than $400 \Omega \cdot \mathrm{m}$ are distinguished, apparently associated with virgin sandstone. Within this layer, zones with low electrical resistivity have been discovered, which may be connected with the zone of clastic rock of rupture. At the distance of 70-80 m, a zone with electrical resistivity less than $70 \Omega \cdot \mathrm{m}$ has been discovered, which may correspond to the zone of higher humidity in the rock mass.

Data on the position of clastic rock in the wall obtained from the analysis of geoelectric section were accounted for when developing the three-dimensional geological-geophysical model. 
Based on the constructed three-dimensional geological-geophysical model, wall's resistance against the geological quarries XIXa, XIX-1, XIX, XVIIIb, XVIIIa, XVIII was predicted. Results are presented in fig. 2 and table 3.

It has been determined from the wall stability analysis that the wall at prospecting lines XIXa, XIX-1, XIX, and XVIII is in a stable state, while at prospecting lines XVIIIa and XVIIIb it is deformed.

Table 3. The results of slope stability analysis of the open-pit wall Таблица 3. Результаты прогноза устойчивости прибортового массива

\begin{tabular}{c|c|r|r|c|c|c|c|c}
\hline Geological cross-section & $Z_{\mathrm{u}}, \mathrm{m}$ & \multicolumn{1}{|c|}{$Z_{\mathrm{l}}, \mathrm{m}$} & \multicolumn{1}{c}{$h, \mathrm{~m}$} & $\alpha$, degrees & $k_{1}$ & $k_{2}$ & $n_{1}$ & $n_{2}$ \\
\hline XIXa & 163.2 & 84.0 & 79.2 & 35 & 0.4 & 0.0 & 1.90 & 2.39 \\
XIX-1 & 206.5 & 88.5 & 118.0 & 25 & 0.5 & 0.1 & 1.59 & 1.88 \\
XIX & 209.2 & 100.1 & 109.1 & 25 & 0.0 & 0.0 & 1.46 & 1.46 \\
XVIIIb & 220.0 & 85.4 & 134.6 & 21 & 0.5 & 0.1 & 1.08 & 1.25 \\
XVIIIa & 195.8 & 89.0 & 106.8 & 22 & 0.1 & 0.0 & 1.06 & 1.10 \\
XVIII & 196.1 & 110.0 & 86.1 & 25 & 0.2 & 0.1 & 1.50 & 1.52
\end{tabular}

$Z_{\mathrm{u}} / Z_{1}$ - elevations of upper and lower lips; $h$ - height of the marginal rock mass; $\alpha$ - overall angle; $k_{1} / k_{2}-$ coefficients of inundation under maximum and minimum inundation levels; $n_{1} / n_{2}$ - factors and safety under inundation $k_{1} / k_{2}$ correspondingly.

Summary. The combination of natural and man-made factors, including hydrogeological conditions of the territory, seasonal and climatic behavior, tectonic faulting of the deposit and shear zones connected with undermining result in the development of a rather complex geological structure of the wall, which includes local deconsolidated and waterlogged zones significantly reducing the stability of the pit slope.

At the trial site of Kedrovsky pit due to spatial and temporal alternation of properties and state of rock within the landslide hazardous zone, the variation range of the factor of safety in six typical sections amounts $n=1.06-2.39$. For that reason the objective prediction of slope stability in similar conditions (in addition to geological survey and hydrogeological observations data analysis) should include geophysical monitoring of anomalous zones origination and development, hereupon creation of a tree-dimensional geological-physical model, and the automated calculation of the factor of safety including repeated selection of the most hazardous section.

\section{REFERENCES}

1. Oparin V. N., Adushkin V. V., Iushkin V. F., Potapov V. P. Influence of natural climate and mininginduced impact on mechanical erosion and seismic noise in the areas of open pit coal mines in Kuzbass. Gornyi informatsionno-analiticheskii biulleten (nauchno-tekhnicheskii zhurnal) = Mining Informational and Analytical Bulletin (scientific and technical journal). 2019; 9: 72-101. DOI: 10.25018/0236-14932019-09-0-72-101 (In Russ.)

2. Panzhin A. A., Panzhina N. A. Study of the stressed-deformed state and structure of rock massif with open geotechnology. Izvestiia Tulskogo Gosudarstvennogo Universiteta. Nauki o Zemle = Proceedings of the Tula State University. Earth Sciences. 2019; 3: 307-317. (In Russ.)

3. Iushkin V. F. On forecasting soil subsidence of soil in the sides of the quarry. Interekspo Geo-Sibir = Interexpo Geo-Siberia. 2019; 132-137. DOI: 10.33764/2618-981X-2019-2-5-132-137 (In Russ.)

4. Dalatkazin T. Sh. Research of the mineral composition of clayey deposits of the weathering crust during geodynamic diagnostics for ensuring the safety of subsoil use objects. Problemy nedropolzovaniia = The Problems of Subsoil Use. 2018; 3: 39-43. DOI: 10.25635/2313-1586.2018.03.039 (In Russ.)

5. Tailakov O. V., Zastrelov D. N., Saltymakov E. A., Makeev M. P., Sokolov S. V., Iarosh A. S. Aquifers depth detection by electron tomography method in Kuzbass conditions. Vestnik nauchnogo tsentra po bezopasnosti rabot v ugolnoi promyshlennosti = Bulletin of Research Center for Safety in Coal Industry (Industial Safety). 2016; 1: 30-34. (In Russ.)

6. Prostov S. M. Interrelation among electrophysical properties of clay rocks, their porosity and moisture saturation. Journal of Mining Science. 2006; 42: 349-359. 
7. Shalaginov A. E., Nevedrova N. N., Shaparenko I. O., Babushkin S. M. Application of methods of electrical exploration with controlled sources for detecting causes of sub-pass-location processes development. Izvestiia TPU. Inzhiniring georesursov = Bulletin of the Tomsk Polytechnic University. Geo Assets Engineering. 2019; 330(4): 26-40. DOI 10.18799/24131830/2019/4/190 (In Russ.)

8. Kaczmarek L., Mieszkowski R., Kolpaczyñski M., Pacanowski Gr. Application of electrical resistivity tomography (ert) in the investigation of quaternary landslide zones, based on the selected regions of plock slope. Studia Quaternaria. 2014; 31(2): 101-107. DOI: 10.2478/squa-2014-0010

9. Hen-Jones R. M., Hughes P. N., Stirling R. A., Glendinning S., Chambers J. E., Gunn D. A., Cui Y. J. Seasonal effects on geophysical-geotechnical relationships and their implications for electrical resistivity tomography monitoring of slope. Acta Geotechnica. 2017. DOI: 10.1007/s11440-017-0523-7

10. Zeybek M., Sanlioglu I., Ozdemir A. Monitoring landslides with geophysical and geodetic observations. Environmental Earth Sciences. 2015; 74: 6247-6263.

11. Santoso B., Uswatun Hasanah M., Setianto. Landslide investigation using self potential method and electrical resistivity tomography (Pasanggrahan, South Sumedang, Indonesia). IOP Conf. Series: Earth and Environmental Science. 2019; 311: 1-8. DOI:10.1088/1755-1315/311/1/012068

12. Karablin M. M., Prostov S. M. Angren coal pit Centralny landslide slope stability analysis based on a three-dimensional geological-geophysical model. Izvestiya vysshikh uchebnykh zavedenii. Gornyi zhurnal = News of the Higher Institutions. Mining Journal. 2020; 3: 39-49. (In Russ.)

Received 25 May 2020

\section{Information about authors:}

Mikhail M. Karablin - mechanical engineering team lead, Kuzbassgiproshakht. E-mail: karablin.mm@gmail.com

Sergei M. Prostov - DSc (Engineering), professor of Theoretical and Geotechnical Mechanics Department, T. F. Gorbachev Kuzbass State Technical University. E-mail: psm.kem@mail.ru

Nikolai A. Smirnov - PhD (Engineering), leading researcher, Innovation Company Kuzbass-NIIOGR. E-mail: smirnovnick@yandex.ru

\section{Оценка влияния гидрогеологических процессов и подработки на устойчивость прибортового массива угольного разреза}

Караблин М. М. ${ }^{1}$, Простов С. М. ${ }^{2}$, Смирнов Н. А. ${ }^{3}$

${ }^{1}$ Кузбасский головной институт по проектированию угледобывающих и углеперерабатывающих предприятий «Кузбассгипрошахт», Кемерово, Россия.

2 Кузбасский государственный технический университет, Кемерово, Россия.

${ }^{3}$ Новационная фирма «КУЗБАСС-НИИОГР», Кемерово, Россия.

\section{Peфepam}

Введение. Достоверность геомеханического прогноза зависит от детальности используемых баз данных о геологическом строении, геометрии и физических свойствах исследуемого массива горных пород. Для повышения точности прогноза устойчивости прибортовых массивов угольных разрезов иелесообразно по результатам обобщения баз данных геологического изучения, гидрогеологического мониторинга, геофизических исследований и маркиейдерских съемок выполнять построение объемных геолого-геофизических моделей, учитьвающих действие основных неблагоприятных факторов, с последующим поиском наиболее опасного сечения.

Цель работы. Прогноз устойчивости прибортового массива согласно разработанному алгоритму на основе объемной геолого-геофизической модели.

Методология. Поиск наиболее опасного сечения участка массива по соотношению сдвигаюших и удерживающих сил в пределах установленных зон с аномальными физическими свойствами.

Результаты. На основе обобщения баз данных геологического изучения, гидрогеологического мониторинга, геофизических исследований методом электротомографии и маркшейдерских съемок разработана объемная геолого-геофизическая модель прибортового массива, нагруженного техногенной системой «отвал сухих пород на гидроотвале», и подработанного подземными горными работами. Выполнен прогноз устойчивости опытного участка массива для фактического положения горных работ, дан сравнительный анализ полученных результатов.

Выводы. Сочетание природных и техногенных факторов, включающих гидрогеологические условия территории, сезонный климатический режим, тектоническую нарушенность месторождения и накладываемые на нее зоны сдвижения, связаннье с подработкой, приводят к формированию весьма сложной геологической структуры прибортового массива, включающей локальные разуплотненные и влагонасыщенные зоны, что существенно снижает устойчивость борта. На опытном участке разреза "Кедровский» вследствие пространственно-временных изменений свойств и состояния горных пород в пределах оползнеопасной зонь диапазон изменения коэффициента устойчивости в шести характерных сечениях составил $n=1,06-2,39$. Поэтому объективный прогноз устойчивости борта в подобных условиях кроме анализа данных 
геологических изысканий и гидрогеологических наблюдений должен включать геофизический мониторинг формирования и развития аномальных зон, создание на этой основе объемной геологофизической модели и автоматизированный расчет коэффициента устойчивости с циклическим выбором наиболее опасного сечения.

Ключевые слова: техногенный массив; подземные воды; устойчивость откосных сооружений; электротомография; объемная геолого-геофизическая модель; коэффициент устойчивости.

\section{БИБЛИОГРАФИЧЕСКИЙ СПИСОК}

1. Опарин В. Н., Адушкин В. В., Юшкин В. Ф., Потапов В. П. О влиянии природно-климатических и техногенных факторов на развитие механо-эрозионных и сейсмоэмиссионных процессов в окрестностях угольных разрезов Кузбасса // ГИАБ. 2019. № 9. С. 72-101. DOI: 10.25018/0236-14932019-09-0-72-101

2. Панжин А. А., Панжина Н. А. Исследование напряженно-деформированного состояния и структуры породного массива при открытой геотехнологии // Известия ТулГУ. 2019. Вып. 3. С. $307-317$.

3. Юшкин В. Ф. О прогнозе оседаний грунтов в бортах карьера // Интерэкспо Гео-Сибирь. 2019. C. 132-137. DOI: 10.33764/2618-981X-2019-2-5-132-137

4. Далатказин Т. Ш. Исследование минерального состава глинистых отложений коры выветривания при выполнении геодинамической диагностики для обеспечения безопасности объектов недропользования // Проблемы недропользования. 2018. № 3. C. 39-43. DOI: 10.25635/23131586.2018.03.039

5. Тайлаков О. В., Застрелов Д. Н., Салтымаков Е. А., Макеев М. П., Соколов С. В., Ярош А. С. Определение глубин залегания водоносных горизонтов методом электротомографии в условиях Кузбасса // Вестник научного центра по безопасности работ в угольной промышленности. 2016. № 1. С. 30-34.

6. Prostov S. M. Interrelation among electrophysical properties of clay rocks, their porosity and moisture saturation // Journal of Mining Science. 2006. No. 42. P. 349-359.

7. Шалагинов А. Е., Неведрова Н. Н., Шапаренко И. О., Бабушкин С. М. Применение методов электроразведки с контролируемыми источниками для выявления причин развития суффозионнопросадочных процессов // Известия ТПУ. Инжиниринг георесурсов. 2019. Т. 330. № 4. С. 26-40. DOI 10.18799/24131830/2019/4/190

8. Kaczmarek L., Mieszkowski R., Kolpaczyñski M., Pacanowski Gr. Application of electrical resistivity tomography (ert) in the investigation of quaternary landslide zones, based on the selected regions of plock slope // Studia Quaternaria. 2014. Vol. 31. No. 2. P. 101-107. DOI: 10.2478/squa-2014-0010

9. Hen-Jones R. M., Hughes P. N., Stirling R. A., Glendinning S., Chambers J. E., Gunn D. A., Cui Y. J. Seasonal effects on geophysical-geotechnical relationships and their implications for electrical resistivity tomography monitoring of slope // Acta Geotechnica. 2017. DOI: 10.1007/s11440-017-0523-7

10. Zeybek M., Sanlioglu I., Ozdemir A. Monitoring landslides with geophysical and geodetic observations // Environmental Earth Sciences. 2015. No. 74. P. 6247-6263.

11. Santoso B., Uswatun Hasanah M., Setianto. Landslide investigation using self potential method and electrical resistivity tomography (Pasanggrahan, South Sumedang, Indonesia) // IOP Conf. Series: Earth and Environmental Science. 2019. No. 311. P. 1-8. DOI:10.1088/1755-1315/311/1/012068

12. Караблин М. М., Простов С. М. Прогноз устойчивости прибортового массива оползня «Центральный» угольного разреза «Ангренский» на основе объемной геолого-геофизической модели // Известия вузов. Горный журнал. 2020. № 3. С. 39-49.

Поступила в редакцию 25 мая 2020 года

\section{Сведения об авторах:}

Караблин Михаил Михайлович - руководитель группы геомеханических работ Кузбасского головного института по проектированию угледобывающих и углеперерабатывающих предприятий «Кузбассгипрошахт». E-mail: karablin.mm@gmail.com

Простов Сергей Михайлович - доктор технических наук, профессор кафедры теоретической и геотехнической механики Кузбасского государственного технического университета имени T. Ф. Горбачева. E-mail: psm.kem@mail.ru

Смирнов Николай Александрович - кандидат технических наук, ведущий научный сотрудник Новационной фирмы «КУЗБАСС-НИИОГР». E-mail: smirnovnick@yandex.ru

Для цитирования: Караблин М. М., Простов С. М., Смирнов Н. А. Оценка влияния гидрогеологических процессов и подработки на устойчивость прибортового массива угольного разреза // Известия вузов. Горный журнал. 2021. № 1. С. 36-44 (In Eng.). DOI: 10.21440/0536-1028-2021-1-36-44

For citation: Karablin M. M., Prostov S. M., Smirnov N. A. Assessing the impact made by groundwater processes and undermining on coal pit wall stability. Izvestiya vysshikh uchebnykh zavedenii. Gornyi zhurnal $=$ News of the Higher Institutions. Mining Journal. 2021; 1: 36-44. DOI: 10.21440/0536-10282021-1-36-44 